\title{
Different sources of market information and product innovativeness $^{1}$
}

\section{Dariusz Dąbrowski ${ }^{2}$}

\begin{abstract}
The purpose of this study is to identify whether the gathering of market information from different sources - i.e. from customers, competitors and other entities - is related to product innovativeness. The relationships proposed so far have not been empirically investigated but they can have important theoretical and practical implications for product innovation. To achieve the purpose of the paper data concerning 287 new products were used by applying confirmatory factor analysis and structural equation modelling. The findings indicate that the obtaining of market information from customers and market entities, other than customers and competitors, has a positive impact on product innovativeness, but there was no such relationship in the case of gathering information from competitors.
\end{abstract}

Keywords: product innovativeness, market information, new product, sources of information.

JEL codes: D83, M31, O31.

\section{Introduction}

Innovation is important because of its potential effect on company performance (Geldes, Felzensztein, \& Palacios-Fenech, 2017; Gierczak-Korzeniowska \& Gołembski, 2017). Firms try to achieve a competitive advantage as well as company growth by introducing innovative products and processes (Brem, Maier, \& Wimschneider, 2016). A classical definition of innovation was given by Schumpeter who proposed that innovation is the reflection of novel outputs of a new good, a new method of production, a new market, a new source of supply or a new organization structure (Schumpeter, 1960). This author also proposed that innovation can be grouped as a product, process or busi-

\footnotetext{
${ }^{1}$ Article received 18 December 2017, accepted 24 April 2018.

${ }^{2}$ Gdańsk University of Technology, Faculty of Management and Economics, Marketing Department, ul. G. Narutowicza 11/12, 80-233 Gdańsk, dariusz.dabrowski@zie.pg.gda.pl.
} 
ness model innovation. All these categories are equally important for a firm, although in this paper we focus on product innovation.

Product innovations are new products, including new services, introduced by companies to the market in order to satisfy their customers' needs in a more effective way (Chang, Bai, \& Li, 2015; Geldes et al., 2017). These innovations can be either technology or market driven. This means that new products can offer new benefits for users by applying new technologies or by applying new solutions proposed by market entities - e.g. customers. Product innovations are important for companies because they can be seen as the critical outcomes of an organization that are observable externally (Chang et al., 2015). They are associated with the differentiation strategy employed by a company to achieve a competitive advantage that is eventually reflected in additional sales and growth. Product innovations are targeted at customers and should satisfy their wants and needs; therefore they require market knowledge and communication with customers during their development. However product innovations differ in terms of their innovativeness. New products bring varying degrees of novelty to the market and empirical research has shown that product innovativeness is related to commercial performance (Bao, Sheng, \& Zhou, 2012). Therefore looking for the drivers of product innovativeness is an important issue because these drivers can be transmitted to the product's commercial performance through product innovativeness.

This work is concerned with obtaining market information and its impact on product innovativeness. Gathering information during new product development (NPD) is a critical task for several reasons. Firstly, a new product is targeted at customers who are its intended buyers and users; hence, opinion and feedback from them is important before a new product is introduced to the market. Secondly, a new product will face a certain amount of competition from products in the same category or even from substitutes; therefore, present and potential rivals should be recognized and analyzed. Thirdly, the overall market situation, with regard to market size and its growth or potential, should be foreseen, because market characteristics will determine the new product's life cycle. Therefore acquiring market information and being market oriented in NPD is reflected in new product innovativeness (Joshi, 2016; Kim \& Atuahene-Gima, 2010).

The extant studies that investigated the impact of acquiring market information on product innovativeness are mixed. On the one hand it was demonstrated that there was no relationship between gathering information and the novelty of a product (Moorman, 1995), but on the other a positive link was found (Hultink, Talke, Griffin, \& Veldhuizen, 2011; H. M. T. Tsai, 2008). These inconsistencies may be the result of the different sources used to acquire information. So far the relationship between gathering market information from different sources and product innovativeness has not been empirically tested and this work addresses this research gap. Therefore the following research ques- 
tion is posed: is obtaining market information from different sources related to product innovativeness? Consequently the purpose of this work is to identify whether gathering market information from different sources is related to product innovativeness. This problem is significant because such knowledge will allow, at least to a certain extent, new product innovativeness to be controlled. As the latter is related to a new product's commercial performance the company would be better equipped to predict market outcomes.

Three different sources are distinguished when acquiring market information, namely: gathering this information from customers, from competitors and from market entities other than customers and competitors. In this way a contribution is made to the present knowledge since extant studies have used an overall construct: i.e. obtaining market information without differentiating gathering market information from various sources when investigating the link between product innovativeness and acquiring market information (Hultink et al., 2011; H. M. T. Tsai, 2008).

The choice of having customers and competitors as separate groups is supported by the concept of market orientation proposed by Narver and Slater (1990) who distinguished between customer and competitor orientations. These two market entities are crucial in the market environment. As it is not intended to complicate the model, other market partners, such as suppliers, commercial intermediaries, industrial institutions and independent experts are considered as a single but heterogeneous group.

This study is focused on high-tech and medium high-tech companies (Hatzichronoglou, 1997) because of their fairly extensive involvement in NPD. Furthermore these industries, in comparison to other groups of firms, face faster technological and market changes. The latter forces high-tech and medium high-tech companies to monitor their markets and gather feedback. Furthermore the concentration is on firms of medium and large size (employing more than 49 people) because such firms are engaged to a higher extent in NPD and gathering market information in comparison with small ones.

The novelty of this work is twofold. Firstly, the research gap of the lack of knowledge regarding the relationship between gathering market information from different sources and product innovativeness in the context of high-tech and medium high-tech companies will be filled. Secondly, the literature on NPD is dominated by studies from US and Western European countries. This work provides evidence from a Central European country.

This paper is organized as follows. It starts by defining terms, providing the theoretical background and developing hypotheses regarding the relationship between gathering market information from different sources and new product innovativeness. Then the methodological aspects of our work, including samples and measures is discussed. Finally, the results of the reliability and validity estimation, of the testing of the model and its implications for theory and practice as well as future research are presented. 


\section{Theoretical background and hypotheses development}

Product innovativeness refers to the degree of 'novelty' manifested by a product. However the term 'product innovativeness' should be clarified because a product can be new, either to the world or to the industry/market, or to the firm (Garcia \& Calantone, 2002). Many studies conceptualize this term with regard to the market (Bao et al., 2012; Fang, 2008) because the most important verification of a new product is its market acceptance. Organizations develop and introduce new products in order to satisfy their customers' needs in a more effective way and thereby gain a competitive advantage as well as increased profit. Therefore product novelty to the customers is the most critical issue. This approach is adopted and defines product innovativeness as the degree to which a new product is new to the industry or market.

The dependence of product innovativeness on obtaining market information can be drawn from the resource-based view (RBV) theory of the firm. The theory assumes that firms can be regarded as bundles of resources that are heterogeneously distributed among them, creating resource differences across companies and this situation persists over a certain period of time. The fundamental principle of the theory states that if a firm has valuable, rare, inimitable and non-substitutable resources, then it is able to achieve a competitive advantage and outcomes over time by configuring its resources in a unique way (Barney, 1991). Wade and Hulland (2004) define resources as assets (i.e. anything that can be used in the company's processes, e.g. machinery, information) and capabilities (i.e. patterns of actions applied to transform assets into products, e.g. skills, new product development processes). The latter includes so-called dynamic capabilities that enable a firm to deploy its tangible and intangible resources to achieve alignment with the changing organizational environment (Teece, Pisano, \& Shuen, 1997). According to this theory product innovativeness can be regarded as an outcome of innovation (K.-H. Tsai, Hsieh, \& Hultink, 2011) and obtaining market information from a given source in NPD may be perceived as a specific dynamic capability. This capability enables a firm to maintain alignment with the current market situation by developing innovative products (Teece et al., 1997). Therefore gathering market information during NPD is likely to influence new product innovativeness.

Customers are a very important source of information for NPD because the potential new product is intended to be bought and used by them. The product is primarily created to satisfy the customers' needs and desires; therefore, knowledge about their requirements is crucial. New product development literature indicates that the voice of the customer should be taken into account at each stage of the NPD process to create competitive product innovation (Drejeriene \& Drejeris, 2017; Kahn, Barczak, Nicholas, Ledwith, \& Perks, 2012). Customers can serve as a source of new ideas and product improvement that can be implemented in the process of NPD, thereby enhancing product innovativeness (De 
Luca \& Atuahene-Gima, 2007; Joshi, 2016). Therefore providing information from customers during several stages of the NPD project can be considered as a dynamic capability according to RBV theory. It has been noticed that a customer-orientated firm tends to improve product innovativeness (Gatignon \& Xuereb, 1997; Han, Namwoon, \& Srivastava, 1998). However an observation has also been made that product innovativeness can be limited by listening too closely to customers due to their limited knowledge of the market and technology (Joshi, 2016). This paper posits that, in general, information from customers will positively influence product innovativeness because suggestions given by customers may be consciously selected to increase product novelty. Thus:

Hypothesis 1: Obtaining market information from customers is positively related to product innovativeness.

Another source of market information during the development of a new product, are competitors. Other companies that offer products that satisfy the same need as the new product create a certain frame of reference. It is common practice within NPD to study competitors' products and their solutions because this can lead to creative ideas (Im \& Workman, 2004). Furthermore information about the present and planned campaigns of rival enterprises is beneficial and this may include their product strategies, processes and promotional activities (Rakthin, Calantone, \& Wang, 2016). To monitor competitors allows a firm to develop a product innovation that is ahead of their competitors' offers (Han et al., 1998). Market information can be directly obtained from competitors by several means, for example, by buying their products, observing their behavior, direct contact (at fairs or during personal meetings), accessing their web-sides or even occasional cooperation. Gathering market information from competitors can be seen as another specific, dynamic capability of a firm. Furthermore such an activity is an expression of the competitor orientation of a firm. It has been shown that competitor orientation is positively related to new product novelty (Im \& Workman, 2004). Therefore the acquiring of market information from competitors can stimulate innovative solutions and further it can be stated that:

Hypothesis 2: Obtaining market information from competitors is positively related to product innovativeness.

During NPD companies try to enhance their market knowledge; therefore, they look for information from different sources. Apart from customers and competitors other market entities may also serve as sources of market information (Bao et al., 2012). Kyriakopoulos (2011) argues that external sources generate more novel information than internal ones and market information from the former tends to exhibit diversity and a fresh perspective (Moorman, 
1995). External sources, other than customers and competitors include, for instance, distribution channel partners, suppliers, independent and industry organizations and experts. For example commercial intermediaries that distribute products are in touch with producers and customers. They may be in possession of some specific and valuable knowledge about the current market situation and upcoming trends. Suppliers are another type of entity that can accumulate market knowledge because they cooperate with different producers (Zhang \& Yang, 2016). Frequently their clients are companies which offer products in the same category. In general new product literature suggests that contact with external parties promotes novel thinking (Moorman, 1995). Hence it is assumed that acquiring information from market sources, other than customers and competitors, can enhance product innovativeness. Therefore:

Hypothesis 3: Obtaining market information from market entities other than customers or competitors (e.g. intermediaries, suppliers, industry institutions) is positively related to product innovativeness.

\section{Methodology}

\subsection{Sample and data collection}

A cross-sectional study, in the form of a traditional mail survey, from November 2013 to March 2014 was conducted. The general content of the study concerned sources of market information and the outcomes of new products. In this work results related to the purpose of this paper are presented and are therefore concentrated on the relationships between gathering market information from different sources and product innovativeness.

The target population consisted of medium high-tech and high-tech Polish firms with more than 49 full-time employees. To identify companies included in this group the OECD classification of industries, according to R\&D intensity was used (OECD, 2013). According to this classification high-tech companies were from industries such as aerospace, computers and electronics, pharmaceutical; and the medium high-tech companies were from electrical industrial machinery, automotive, medical appliances, chemical and other industries. A sampling frame of these companies was obtained from the HBI (Hoppenstedt Bonnier Information) database, one of the directories of Polish companies. The sampling frame included 1,813 units, and 792 firms from this were selected, due to budget constraints. Simple random method, with use of RND procedure in Excel was applied, to obtain a list of 792 companies. Subsequently these firms were requested to take part in our study. Five requests were not delivered and two refusals were received because of their company's policy of not participat- 
ing in surveys. A total of 165 companies participated in the survey; hence the response rate was about $21 \%$.

When obtaining data a method that relies on researching unsuccessful and successful new products was applied, because product innovativeness is related to new product success. The method is quite often used in new product development studies (Dabrowski, 2008; Millson, 2015) because it allows an increase in the variance of our focal endogenous variable - i.e. new product innovativeness.

In each firm the survey was given to the person in the highest position (e.g. the Managing Director). Each recipient was sent two versions of the same questionnaire, one to be completed in relation to a product regarded as a failure and the second - as a success. It was explained that, in the case of a successful new product, the company had achieved its NPD purposes and in the case of an unsuccessful one - not. Each recipient was asked to choose two new products, a success and a failure, that had been launched at least six months before the survey request. Subsequently the recipients were asked to forward the questionnaires to the people involved in the relevant projects (e.g. professionals from engineering, $R \& D$, marketing or production function). As the response rate for surveys is usually low, two follow-up letters were send to the recipients asking them to return the questionnaires by sending two follow-up letters. After discarding the incorrectly completed questionnaires a total of 287 completed questionnaires were received, 154 relating to successful, and 133 to unsuccessful new product projects.

A pilot study among fifteen new product practitioners was made before conducting the survey in order to test and verify the questionnaire. The pilot study was conducted face-to-face and allowed for immediate feedback besides simply answering the questions. The firms for the pilot study were selected for convenience in the region of Gdansk as a meeting with the company's representatives had to be arranged.

The final sample can be described in terms of company size and industry type. The sample included the following proportions of companies regarding their size, expressed in terms of full-time employees: $70.8 \%$ of firms employed 50 to 250 people, $19.9 \%$ employed 250 to 999 people and $9.9 \%$ employed more than 999 people. In terms of industry type the structure of the sample was as follows: manufacturing of machinery and equipment $-38.6 \%$; electrical equipment $-22.3 \%$; chemicals and chemical products $-12.0 \%$; computer, electronic and optical products $-7.8 \%$; motor vehicles $-6.6 \%$; other transport equipment $-4.2 \%$; pharmaceutical products $-4.2 \%$; medical products $-3.6 \%$; and weapons and ammunition $-0.6 \%$.

\subsection{Measures}

The chosen unit of analysis is the new product development project because the measures included in the study - i.e. new product innovativeness and ob- 
Table 1. Constructs, reliability and validity coefficients

\begin{tabular}{|c|c|c|c|c|c|}
\hline Constructs & Items (statements) & $\lambda$ & $t$-values & CR & AVE \\
\hline $\begin{array}{l}\text { Product innova- } \\
\text { tiveness }\end{array}$ & & & & 0.92 & 0.71 \\
\hline \multirow{5}{*}{$\begin{array}{l}\text { Adopted from: } \\
\text { (Hultink et al., } \\
\text { 2011) }\end{array}$} & $\begin{array}{l}\text { When the new product was launched it } \\
\text { was innovative for the market }\end{array}$ & 0.82 & 34.9 & & \\
\hline & $\begin{array}{l}\text { When the new product was launched } \\
\text { there were no comparable products on } \\
\text { the market }\end{array}$ & 0.82 & 25.0 & & \\
\hline & $\begin{array}{l}\text { When the new product was launched it } \\
\text { was new for the product category }\end{array}$ & 0.84 & 30.5 & & \\
\hline & $\begin{array}{l}\text { When the new product was launched it } \\
\text { was the first of its kind }\end{array}$ & 0.85 & 42.3 & & \\
\hline & $\begin{array}{l}\text { When the new product was launched it } \\
\text { had features that did not yet exist }\end{array}$ & 0.88 & 41.6 & & \\
\hline \multirow[t]{5}{*}{$\begin{array}{l}\text { Information from } \\
\text { customers }\end{array}$} & & & & 0.83 & 0.55 \\
\hline & $\begin{array}{l}\text { We gathered market information from } \\
\text { potential buyers }\end{array}$ & 0.71 & 14.6 & & \\
\hline & $\begin{array}{l}\text { Target customers were a source of infor- } \\
\text { mation about their needs }\end{array}$ & 0.66 & 10.2 & & \\
\hline & $\begin{array}{l}\text { We gathered market information from } \\
\text { customers on different stages of NPD }\end{array}$ & 0.76 & 20.4 & & \\
\hline & $\begin{array}{l}\text { We obtained market information several } \\
\text { times from future customers }\end{array}$ & 0.83 & 13.2 & & \\
\hline \multirow[t]{5}{*}{$\begin{array}{l}\text { Information from } \\
\text { competitors }\end{array}$} & & & & 0.79 & 0.49 \\
\hline & $\begin{array}{l}\text { We gathered market information from } \\
\text { potential competitors (e.g. at fairs, meet- } \\
\text { ings or through personal contacts) }\end{array}$ & 0.57 & 11.9 & & \\
\hline & $\begin{array}{l}\text { We analysed competitive products to the } \\
\text { new product }\end{array}$ & 0.74 & 17.6 & & \\
\hline & $\begin{array}{l}\text { Web sites of prospective competitors, } \\
\text { their materials and promotional activities } \\
\text { were a source of information about them }\end{array}$ & 0.79 & 21.4 & & \\
\hline & $\begin{array}{l}\text { We observed the behaviour of prospec- } \\
\text { tive competitors }\end{array}$ & 0.67 & 15.7 & & \\
\hline \multirow[t]{5}{*}{$\begin{array}{l}\text { Information from } \\
\text { other entities }\end{array}$} & & & & 0.91 & 0.71 \\
\hline & $\begin{array}{l}\text { Other market entities (e.g. intermediar- } \\
\text { ies, suppliers, trade associations, experts) } \\
\text { were a source of information about the } \\
\text { market for this product }\end{array}$ & 0.79 & 23.9 & & \\
\hline & $\begin{array}{l}\text { Through these other entities we have } \\
\text { gained information about future buyers } \\
\text { and competitors }\end{array}$ & 0.84 & 23.2 & & \\
\hline & $\begin{array}{l}\text { We contacted the other entities several } \\
\text { times to gain information about the } \\
\text { market }\end{array}$ & 0.87 & 34.4 & & \\
\hline & $\begin{array}{l}\text { We obtained a lot of market information } \\
\text { from these entities }\end{array}$ & 0.86 & 30.4 & & \\
\hline
\end{tabular}

$\lambda$ - Standardised loadings; CR - Construct Reliability; AVE - Average Variance Extracted. 
taining market information - are project specific. Therefore the respondents were asked to relate their responses in the questionnaire to a specific project.

The questionnaire was created to measure the following four constructs: product innovativeness, gathering market information from customers, gathering market information from competitors, gathering market information from other market entities. For each construct a reflective multi-item scale was used. Each item was measured by using the five-point Likert scale and the respondents were asked to state their level of agreement with a given statement on a range from 'totally disagree' to 'totally agree. The constructs and their respective items were examined in the pilot study and are presented in Table 1. Statements presented in Table 1 were used in the questionnaire to measure the constructs.

To measure product innovativeness the scale used by (Hultink et al., 2011) was adopted. The measure contained five items, given in Table 1 that aimed at measuring the new product's market innovativeness, newness for the product category, comparison to other products and new product features.

Constructs to measure the gathering of market information from customers, from competitors and from other entities in an NPD project were developed. For each four items were created, as shown in Table 1, in such a way as to gauge the essence of the construct (Churchill, 1979). In the case of acquiring information from customers the items aimed at obtaining market information during an NPD project from potential buyers at various stages of the project, as well as the frequency of acquiring market information. The items created to measure the acquisition of information from competitors looked at market information gathered from competitors (e.g. at fairs or during meetings), analyzing competitive products, observing rivals' behavior and promotional campaigns. In the case of acquiring information from other entities the items reflected the acquisition of market information from sources other than customers and competitors (e.g. intermediaries, suppliers, trade associations and experts) and the intensity and frequency of such activity.

\section{Results}

The analysis was started with a confirmatory factor analysis (CFA) in order to evaluate the measurement model. To perform the CFA, a restriction on the whole set of items to load only on their respective constructs was made, and the covariance among the constructs was assessed freely. The CFA was carried out by using Mplus v.7.2 with a maximum likelihood estimator (MLR) that is robust to data non-normality (Muthén, Muthén, \& Asparouhov, 2016). The chisquare test and several additional goodness-of-fit measures were applied to test the model fit because the chi-square test is sensitive to sample size. The addi- 
tional fit measures were as follows (Brown, 2015): Root Mean Square Error of Approximation (RMSEA), Standardized Root Mean Square Residual (SRMR), Comparative Fit Index (CFI), Tucker Lewis Index (TLI). The measurement model fitted the data quite well: $\chi^{2}(113)=210.368 ; p<0.0001$; SRMR $=0.047$; RMSEA $=0.055 ; \mathrm{CFI}=0.955 ; \mathrm{TLI}=0.946$. The value of 0.08 is a critical one for both the RMSEA and the SRMR indices and the results do not exceed this. The indices TLI and CFI should not be lower than 0.90 , and the results are within the acceptable range. Additionally the ratio $\chi^{2} / d f$ is 1.86 and is less than 3 . The estimates of the standardized loadings of all the items are significant (the lowest $t$-value is 10.20) and the items load on their factors with a value of at least 0.57 (Hair, Black, Babin, \& Anderson, 2014). The average variance extracted (AVE) exceeds 0.50 for each of the four constructs, apart from gathering market information from competitors (Table 1). However its value is equal to 0.49 and is only slightly lower than the cut-off one. Having all other indices in the proper ranges, it can be concluded that these results indicate an acceptable convergent validity of the measurement model.

The square-root of the AVE was calculated for the constructs to evaluate the discriminant validity of the measurement model. The results are presented in Table 2 in which the construct correlations are given in off-diagonal cells and the values of the square-root of AVE are shown in cells diagonally. With regard to each construct the square-root of the AVE exceeds the highest correlation among the latent factors involving the focal factor; hence providing proof for an adequate discriminant validity (Fornell \& Larcker, 1981).

Table 2. Constructs correlations and discriminant validity

\begin{tabular}{|l|c|c|c|c|c|c|}
\hline & Average & Std. dev. & $\mathbf{1}$ & $\mathbf{2}$ & $\mathbf{3}$ & $\mathbf{4}$ \\
\hline $\begin{array}{l}\text { 1. Information from } \\
\text { customers }\end{array}$ & 3.6 & 1.0 & 0.741 & & & \\
\hline $\begin{array}{l}\text { 2. Information from } \\
\text { competitors }\end{array}$ & 3.6 & 1.0 & $0.340^{\star * *}$ & 0.699 & & \\
\hline $\begin{array}{l}\text { 3. Information from } \\
\text { other entities }\end{array}$ & 2.7 & 1.1 & $0.215^{\star *}$ & $0.351^{\star * *}$ & 0.842 & 0.843 \\
\hline $\begin{array}{l}\text { 4. Product innovative- } \\
\text { ness }\end{array}$ & 2.8 & 1.3 & $0.173^{\star}$ & $0.036 \mathrm{~ns}$ & $0.177^{\star *}$ & \\
\hline
\end{tabular}

Off-diagonal: construct correlations; along-diagonal: square-root of AVE; ns - non significant; ${ }^{*} p<0.05 ;{ }^{* *} p<0.01 ;{ }^{* *} p<0.001$.

The composite reliability (CR) measure was computed to evaluate the construct reliabilities. The CR values are shown in Table 1 and all are well above the recommended level of 0.7 , which demonstrates the internal reliability of the constructs (Bagozzi \& Yi, 2012). Altogether, with regard to the preced- 


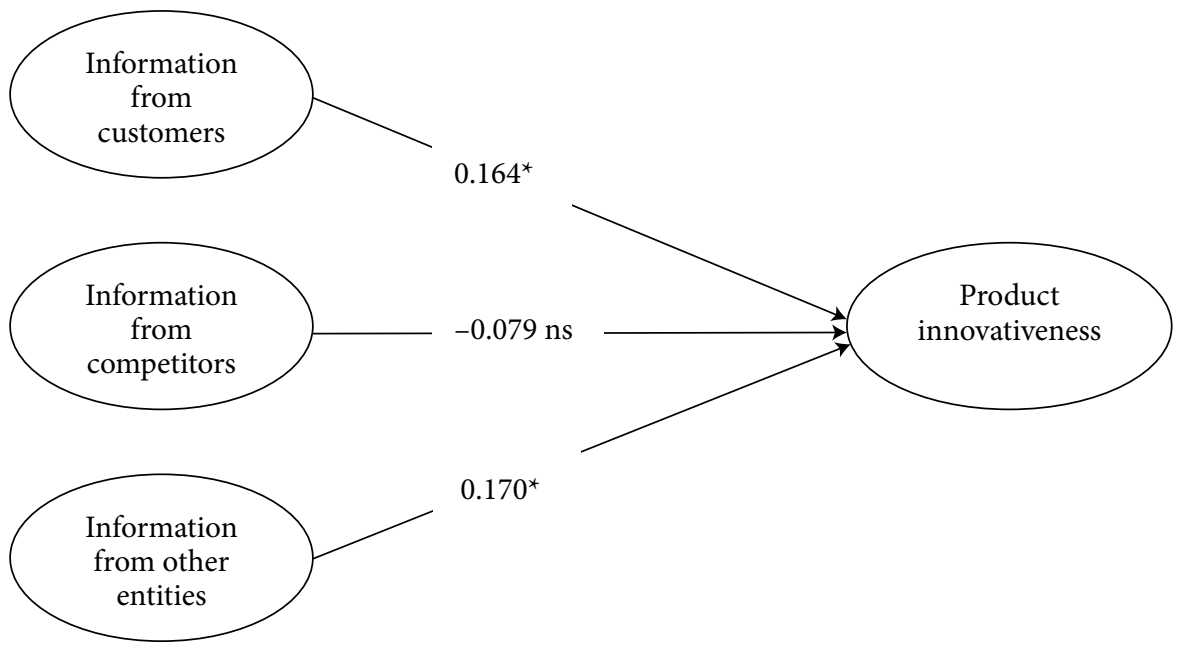

Figure 1. Results of the structural model estimation

Goodness-of-fit statistics: $\chi^{2}(113)=210.367 ; p<0.0001$; SRMR $=0.047$; RMSEA $=0.055$; $\mathrm{CFI}=0.955 ; \mathrm{TLI}=0.946$; Notes: ${ }^{\star} p<0.05 ; \mathrm{ns}-$ not significant.

ing analyses and results, it can be concluded that the measurement model is acceptable.

After validating the measurement model, the structural model (Figure 1) was evaluated to test the hypotheses. Structural equation modelling (SEM) by using Mplus v.7.2 with the MLR estimator was performed. The structural model had an acceptable fit for the data: $\chi^{2}(113)=210.367 ; p<0.0001$; SRMR $=0.047$; RMSEA $=0.055$; CFI $=0.955$; TLI $=0.946$. The values of all the fit measures are within acceptable ranges. Furthermore the ratio of $\chi^{2}$, to the number of degree of freedoms $(d f=113)$ equals 1.86 and is lower than the critical value of 3 (Hair et al., 2014).

The results of verifying the hypotheses $\mathrm{H} 1-\mathrm{H} 3$ are presented in Table 3. Hypothesis $\mathrm{H} 1$ posits that gathering market information from customers in NPD would positively affect product innovativeness and the outcomes support $\mathrm{H} 1$ because an increase in obtaining the information during NPD leads to greater product innovativeness $(\beta=0.164 ; p<0.05)$.

Table 3. Results of testing hypotheses H1-H3

\begin{tabular}{|l|c|c|c|}
\hline \multicolumn{1}{|c|}{ Hypotheses } & $\begin{array}{c}\text { Estimate } \\
\text { (standard) }\end{array}$ & $\boldsymbol{p}$-value & Result \\
\hline $\begin{array}{l}\text { H1 Information from customers } \rightarrow \text { Product in- } \\
\text { novativeness }\end{array}$ & 0.164 & 0.033 & Supported \\
\hline $\begin{array}{l}\text { H2 Information from competitors } \rightarrow \text { Product } \\
\text { innovativeness }\end{array}$ & -0.079 & 0.341 & Not supported \\
\hline
\end{tabular}




\begin{tabular}{|l|l|l|l|}
\hline $\begin{array}{l}\text { H3 Information from other entities } \rightarrow \text { Product } \\
\text { innovativeness }\end{array}$ & 0.170 & 0.020 & Supported \\
\hline
\end{tabular}

In hypothesis $\mathrm{H} 2$, it was expected that obtaining market information from competitors during the NPD process would increase product innovativeness. Contrary to expectations, $\mathrm{H} 2$ is not supported by the results. No relationship between information obtained from competitors and product innovativeness $(\beta=-0.079 ; n s)$ was found.

Hypothesis $\mathrm{H} 3$ proposed that the obtaining of information from other entities during NPD would positively affect new product innovativeness. Evidence was found that this is indeed the case. An increase in the information gleaned from other entities during the NPD process leads to higher product innovativeness $(\beta=0.170 ; p<0.05)$. This supports hypothesis $\mathrm{H} 3$.

\section{Discussion and conclusions}

In this study it was observed that obtaining information from customers has a positive effect on a new product innovativeness. Customers play a central role in the marketing concept and gathering market information from this crucial source promotes the inclusion of 'the voice of customer' in NPD. By listening to the customer a company is opening itself to current and future market needs. Information from potential buyers can enhance product innovativeness because customers usually have experience of using similar products and are able to suggest new and useful solutions from a user's perspective during NPD (Lin, Che, \& Ting, 2012). Some customers, individuals or organizations are very innovative. Therefore gathering ideas and new solutions proposed by the innovative buyers, can positively influence product innovativeness. This result is consistent with innovation literature suggesting that a company needs to be in contact with users to break from its established thinking (Han et al., 1998; Kyriakopoulos, 2011). A manufacturer's perspective can be different from that of the customer because the manufacturer is likely to concentrate on the production and technological aspects of a new product. Sometimes a concept proposed by potential buyers might be neither innovative nor feasible. In such cases the role of the producer is to select new and technologically achievable propositions. Therefore listening carefully to customers, collecting various ideas from them and selecting new and feasible suggestions, results in increasing new product innovativeness.

The findings showed that obtaining information from competitors has no effect on new product innovativeness. One reason for this could be rivalry within a particular industry. A competitive new product introduced to the market by one firm is a threat for other companies who sell products of the same product 
category. Hence competitors are hesitant when it comes to helping the NPD of a potential rival. Even so it is important to know competitors' solutions and future development plans, but a strategy of copying their concepts will not enhance new product innovativeness. This result is in line with findings of Han et al. (1998) who showed no correlation between competitor orientation and technical innovations. Another plausible justification of such a result would be a high specialization in high-tech and medium high-tech industries so that no comparable solutions are provided by competitors.

In this study the gathering of market information from other market entities appeared to have a positive effect on product innovativeness. The category of 'other entities' covers all potential market sources that are neither customers nor competitors. This group includes, for example, commercial intermediaries, suppliers, industry organizations and experts from universities or other institutions. The entities in this group may possess knowledge about various aspects of the new product - usually specific to their function - that can increase its innovativeness. One example are commercial intermediaries who might have information about recent market trends because they distribute different merchandise within the same category as the new product. According to Johansson and Nonaka (1987), firms such as Sony and Canon value direct contacts with commercial intermediaries because they believe that, in this way, information about consumers' attitudes and behaviors can be gained. Another example are suppliers who may have information about new technologies implemented in competitors' products because they provide materials or parts for similar items. The next example are industry organizations or experts whose knowledge may be used to enhance new product innovativeness. The results of this study suggests that within this heterogeneous group are such sources of information from whom gathering market information positively influence product innovativeness.

This study offers some managerial implications. To increase new product innovativeness, it is recommended that high-tech and medium high-tech companies focus on gathering market information from customers. These firms are recommended to obtain market information for the entire NPD project, directly from customers, both through formal marketing research or informal contacts. The latter should be very efficient in the case of innovative organizational clients who respond, and are able to foresee industry as well as market trends. Following suggestions from these customers can lead to innovative solutions. Obtaining market information from customers can be seen as a continuous process in the whole NPD project. At the beginning of a project, customers can help in identifying opportunities for product innovation or create new product concepts. Furthermore, in the next stages of NPD project, feedback from customers is essential to verify the current advancement of the project. This feedback can be gained from customers, for example, through concept testing, prototype or product use testing or marketing testing (Crawford \& Di 
Benedetto, 2011). All of these marketing research actions involve customers who can evaluate and suggest further improvements of a new product. Therefore it is recommended that high-tech and medium high-tech companies gather information from potential customers in NPD several times and at different stages of the NPD project. Product innovativeness can be enhanced through carefully listening to customers, reasonable selection and the incorporation of suggestions and improvements proposed by customers.

On the basis of these findings it is not possible to demonstrate that gathering market information from competitors will influence product innovativeness. According to the results the gathering of market information from competitors - by making contact with them through personal contacts, studying their products or monitoring web sites or promotional activities - will not be positively reflected in product innovativeness. This probably means that a company is applying a follower strategy, that leads to the imitation of existing solutions instead.

The results showed that there are other market partners - such as commercial intermediaries, suppliers, industrial or independent experts - who could be potential sources of market information to improve product innovativeness. Obtaining market information from these entities has a positive effect on product innovativeness and such activities can be recommended to increase product novelty. However it is not possible to delineate a specific partner in this group because of its heterogeneity.

This study has some limitations. Firstly, the results are limited to the population of high-tech and medium high-tech companies that employ more than 49 people in one country. Hence any generalization on the results should be made with caution for a specific firm. Further research could be performed to study the relationships of interest in other industries, as well as in small firms and in different countries. Secondly, the group of market entities, other than customers and competitors, is a heterogeneous. It is worth dividing this group into homogeneous entities because acquiring market information from other market partners is positively related to product innovativeness. For example, the relationship between product innovativeness and obtaining market information from suppliers, commercial intermediaries and industry experts may be examined. A closer look into these subgroups may reveal which of these sources provides information that enhances innovativeness. Thirdly, this study did not investigate differences among various groups in terms of company size or R\&D intensity, with regard to the relationships of interest. Therefore, further studies could address this issue. 


\section{References}

Bagozzi, R. P., \& Yi, Y. (2012). Specification, evaluation, and interpretation of structural equation models. Journal of the Academy of Marketing Science, 40(1), 8-34. doi.org/10.1007/s11747-011-0278-x

Bao, Y., Sheng, S., \& Zhou, K. Z. (2012). Network-based market knowledge and product innovativeness. Marketing Letters, 23(1), 309-324. doi.org/10.1007/s11002-011-9155-0

Barney, J. (1991). Firm resources and sustained competitive advantage. Journal of Management, 17(1), 99-120. doi.org/10.1177/014920639101700108

Brem, A., Maier, M., \& Wimschneider, C. (2016). Competitive advantage through innovation: the case of Nespresso. European Journal of Innovation Management, 19(1), 133-148. doi.org/10.1108/EJIM-05-2014-0055

Brown, T. A. (2015). Confirmatory Factor Analysis for Applied Research (2nd ed.). New York: The Guilford Press.

Chang, J., Bai, X., \& Li, J. J. (2015). The influence of leadership on product and process innovations in China: the contingent role of knowledge acquisition capability. Industrial Marketing Management, 50, 18-29. doi.org/10.1016/j.indmarman.2015.04.014

Churchill, G. (1979). A paradigm for developing better measures of marketing constructs. Journal of Marketing Research, 16(1), 64-73. doi.org/10.2307/3150876

Crawford, M., \& Di Benedetto, A. (2011). New products management (10th ed.). New York: McGraw-Hill Irwin. doi.org/10.1016/0923-4748(93)90075-T

Dabrowski, D. (2008). New product practices and performance of German appliances companies. Argumenta Oeconomica, 2(21), 153-176.

De Luca, L. M., \& Atuahene-Gima, K. (2007). Market knowledge dimensions and cross-functional collaboration: Examining the different routes to product innovation performance. Journal of Marketing, 71(January), 95-112. doi.org/10.1509/jmkg.71.1.95

Drejeriene, E., \& Drejeris, R. (2017). Systematic approach to a new service ideas conceptualisation: quantitative decision making. Inzinerine Ekonomika-Engineering Economics, 28(3), 323-333. doi.org/10.5755/j01.ee.28.3.14752

Fang, E. (2008). Customer participation and the trade-off between new product innovativeness and speed to market. Journal of Marketing, 72(4), 90-104. doi.org/10.1509/ jmkg.72.4.90

Fornell, C., \& Larcker, D. F. (1981). Evaluating structural equation models with unobservable variables and measurement error. Journal of Marketing Research, 18(1), 39-50. doi.org/10.2307/3151312

Garcia, R., \& Calantone, R. (2002). A critical look at technological innovation typology and inovativeness terminology: a literature review. Journal of Product Innovation Management, 19, 110-132.

Gatignon, H., \& Xuereb, J. (1997). Strategic orientation of the firm and new product performance. Journal of Marketing Research, 34(1), 77-90. doi.org/10.2307/3152066

Geldes, C., Felzensztein, C., \& Palacios-Fenech, J. (2017). Technological and non-technological innovations, performance and propensity to innovate across industries. The case of an emerging economy. Industrial Marketing Management, 61, 55-66. doi.org/10.1016/j.indmarman.2016.10.010 
Gierczak-Korzeniowska, B., \& Gołembski, G. (2017). Benchmarking in the process of creating a culture of innovation in hotel companies. Economics and Business Review, 17(2), 101-113. doi.org/10.18559/ebr.2017.2.6

Hair, J. F., Black, W. C., Babin, B. J., \& Anderson, R. E. (2014). Multivariate Data Analysis (7th ed.). Edinburgh Gate: Pearson Education.

Han, J. K., Namwoon, K., \& Srivastava, R. K. (1998, October). Market orientation and organizational performance: is innovation a missing link? Journal of Marketing, 62, 30-45. doi.org/10.2307/1252285

Hatzichronoglou, T. (1997). Revision of the high-technology sector and product classification. OECD Science, Technology and Industry Working Papers, 1997/02, 26. doi. org/10.1787/134337307632

Hultink, E. J., Talke, K., Griffin, A., \& Veldhuizen, E. (2011). Market information processing in new product development: the importance of process interdependency and data quality. IEEE Transactions on Engineering Management, 58(2), 199-211. doi.org/10.1109/TEM.2009.2034254

Im, S., \& Workman, J. P. (2004). Market orientation, creativity, and new product peformance in high-technology firms. Journal of Marketing, 68(April), 114-132. doi.org/10.1509/jmkg.68.2.114.27788

Johansson, J. K., \& Nonaka, I. (1987). Market research the Japanase way. Harvard Business Review, 65(3), 1-5.

Joshi, A. W. (2016). When does customer orientation hinder (help) radical product innovation? The role of organizational rewards. Journal of Product Innovation Management, 33(4), 435-454. doi.org/10.1111/jpim.12301

Kahn, K. B., Barczak, G., Nicholas, J., Ledwith, A., \& Perks, H. (2012). An examination of new product development best practice. Journal of Product Innovation Management, 29(2), 180-192. doi.org/10.1111/j.1540-5885.2011.00888.x

Kim, N., \& Atuahene-Gima, K. (2010). Using exploratory and exploitative maket learning for new product development. Journal of Product Innovation Management, 27(4), 519-536. doi.org/10.1111/j.1540-5885.2010.00733.x

Kyriakopoulos, K. (2011). Improvisation in product innovation: the contingent role of market information sources and memory types. Organization Studies, 32(8), 1051-1078. doi.org/10.1177/0170840611410833

Lin, R. J., Che, R. H., \& Ting, C. Y. (2012). Turning knowledge management into innovation in the high-tech industry. Industrial Management \& Data Systems, 112(1), 42-63. doi.org/10.1108/02635571211193635

Millson, M. R. (2015). Exploring the nonlinear impact of organizational integration on new product market success. Journal of Product Innovation Management, 32(2), 279-289. doi.org/10.1111/jpim.12243

Moorman, C. (1995). Organizational market information processes: cultural antecedents and new product outcomes. Journal of Marketing Research (JMR), XXXII(3), 318-335. doi.org/10.2307/3151984

Muthén, B. O., Muthén, L., \& Asparouhov, T. (2016). Regression and mediation analysis using mplus. Los Angeles: CA: Muthen \& Muthen.

Narver, J. C., \& Slater, S. F. (1990). The effect of a market orientation on business profitability. Journal of Marketing, 54(4), 20-35. doi.org/10.2307/1251757 
OECD. (2013). OECD science, technology and industry scoreboard 2013. doi.org/10.1787/ sti_scoreboard-2013-en

Rakthin, S., Calantone, R. J., \& Wang, J. F. (2016). Managing market intelligence: The comparative role of absorptive capacity and market orientation. Journal of Business Research, 69(12), 5569-5577. doi.org/10.1016/j.jbusres.2016.03.064

Schumpeter, J. A. (1960). Teoria rozwoju gospodarczego. Warszawa: PWE.

Teece, D., Pisano, G., \& Shuen, A. (1997). Dynamic capabilities and strategic management. Strategic Management Journal, 18(7), 509-533. doi.org/10.1016/B978-07506-7088-3.50009-7

Tsai, H. M. T. (2008). The influences of organizational memory and market information processes on product innovation. Proceedings of the 4th IEEE International Conference on Management of Innovation and Technology, ICMIT, 397-401. doi. org/10.1109/ICMIT.2008.4654397

Tsai, K.-H., Hsieh, M.-H., \& Hultink, E. J. (2011). External technology acquisition and product innovativeness: the moderating roles of R\&D investment and configurational context. Journal of Engineering and Technology Management - JET-M, 28(3), 184-200. doi.org/10.1016/j.jengtecman.2011.03.005

Wade, M., \& Hulland, J. (2004). The resource-based view and information systems research: review, extension, and suggestions for future research. MIS Quarterly, 28(1), 107-142. doi.org/10.2307/25148626

Zhang, H., \& Yang, F. (2016). The impact of external involvement on new product market performance: An analysis of mediation and moderation. Industrial Management \& Data Systems, 116(8), 1520-1539. doi.org/10.1108/IMDS-11-2015-0485 